José Florencio F. Lapeña, Jr., MA, MD

Department of Otorhinolaryngology College of Medicine, University of the Philippines Manila, Philippines

Department of Otorhinolaryngology Head and Neck Surgery

East Avenue Medical Center, Diliman

Quezon City, Philippines

\section{On Research Integrity and Ethical Publication, Authorship and Accreditation}

In 2013, multiple articles reporting the clinical trial of valsartan, an antihypertensive drug of more than US\$ 1 billion annual sales from Novartis, were retracted due to data falsification. ${ }^{1,2}$ These included the Kyoto Heart Study presented by Dr. Hiroaki Matsubara at the European Society of Cardiology 2009 Congress and subsequently published in the European Heart Journal $(E H J){ }^{3,4}$ Aside from retraction of this article by EHJ, the American Heart Association (AHA) also retracted five papers published in three of its journals -- Circulation, Circulation Research, and Hypertension. ${ }^{4}$ Novartis employees were involved in the conduct and analysis of the Kyoto Heart Study and a second investigator-initiated trial, the Jikei Heart Study, ${ }_{1}^{5}$ although their participation was not acknowledged in publications and presentations of the data, while a Novartis employee who allegedly manipulated statistical data was listed as one of the academic authors, without disclosing the relation with the company. ${ }^{4,6}$

This scandal has severely damaged scientific integrity in Japan and set the stage for the "Tokyo Declaration on Research Integrity and Ethical Publication in Science and Medicine in the Asia Pacific Region" adopted at the 2013 Convention of the Asia Pacific Association of Medical Journal Editors (APAME) held in Tokyo from 2 to 4 August 2013, and co-published by Journals linked to APAME and listed in the Index Medicus for the South East Asian Region (IMSEAR) and the Western Pacific Region Index Medicus (WPRIM), including the Philippine Journal of Otolaryngology Head and Neck Surgery, with a Special Announcement in this issue. ${ }^{7}$

At the core of research integrity and ethical publication is responsible and accountable authorship. The ICMJE "Uniform Requirements for Manuscripts Submitted to Biomedical Journals" has been replaced by the "Recommendations for the Conduct, Reporting, Editing, and Publication of Scholarly Work in Medical Journals." ${ }^{\prime 8}$ An important change under these new guidelines is an additional criterion for authorship, totaling four (4) instead of three (3) criteria.

The ICMJE recommends that authorship be based on the following 4 criteria: ${ }^{8}$

- Substantial contributions to the conception or design of the work; or the acquisition, analysis, or interpretation of data for the work; AND

- Drafting the work or revising it critically for important intellectual content; AND

- Final approval of the version to be published; AND

- Agreement to be accountable for all aspects of the work in ensuring that questions related to the accuracy or integrity of any part of the work are appropriately investigated and resolved.

In addition to being accountable for the parts of the work he or she has done, an author should be able to identify which co-authors are responsible for specific other parts of the work. In addition, authors should have confidence in the integrity of the contributions of their co-authors. One cannot be listed as a co-author for the credit it brings, without being equally accountable in case of discredit. For example, consultant advisers and seniors who would consider adding their 
names as co-authors of a junior resident, are equally accountable for research misconduct (such as data fabrication, falsification, plagiarism), and cannot lay the blame on one (usually junior) author.

While all those designated as authors should meet all four criteria for authorship, and all who meet the four criteria should be identified as authors, those who do not meet all four criteria should be acknowledged. Hence, it is more appropriate for consultant advisers and seniors who do not meet all four criteria for authorship to be acknowledged in this manner.

Our journal seeks to maintain the highest standards of biomedical publication, and fully supports the APAME Tokyo Declaration on Research Integrity and Ethical Publication in Science and Medicine in the Asia - Pacific Region as well as the ICMJE Recommendations for the Conduct, Reporting, Editing, and Publication of Scholarly Work in Medical Journals. Multiple accreditations and indexing are testimony to these standards.

It was surprising therefore, that a letter from the Commission on Higher Education Journal Accreditation System dated 26 April 2013, which we received 26 May 2013, informed us of our reaccreditation under Category B based on the "recommendation of the panel of evaluators" who "pointed out the need to improve the journal's refereeing system, regularity of publication/circulation and timeliness."

I respectfully responded to these remarks ${ }^{10}$ stating that:

the Philipp J Otolaryngol Head Neck Surg is one of the few consistently compliant journals accredited by the National Journal Selection Committee of the Philippine Council for Health Research and Development, Department of Science and Technology. Our journal has a reputable loco-regional stature evidenced by international contributions from the USA, Japan, Turkey, Malaysia, India and Brunei, and has consistently been recognized as a benchmark journal by the Philippine Association of Medical Journal Editors and Asia Pacific Association of Medical Journal Editors. It functions as the de facto ASEAN Journal in the field of Otolaryngology Head and Neck Surgery.

It is always regularly published on time, and indexed in the Health Research and Development Network (HERDIN-NeON) supported by the PCHRD-DOST; Philippine Journals On Line (PhilJOL) and Asia Journals On Line (AsiaJOL) supported by the International Network for the Availability of Scientific Publications (INASP); the Western Pacific Region Index Medicus (WPRIM) of the World Health Organization (WHO), APAMED Central and the
Index Copernicus"' Journals Master List. It has always met the accreditation criteria of these services. The journal's online peer review system is used as an example for other local journals, including in National Medical Writing and Reviewing Workshops organized by the PCHRD (2012 Cebu and Davao, 2013 Baguio and Iloilo), in the Philippine National Health Research System Week (2011 Bacolod, 2012 Manila, 2013 Laoag) as well as for regional journals in Medical Writing and Review Workshops held in Brunei, Singapore, Malaysia, Vietnam and Cambodia. Several local and regional journals have been thus assisted by us in their editing and peer review systems.

As a Category A Accredited Research Journal (Batch 1) for 2009 - 2012 per Commission on Higher Education (CHED) Memorandum Order No. 09 s. 2010 and Resolution No. 477-2009, effective December 9, 2009 (signed May 26, 2010), our journal has faithfully complied with all the terms of the JAS, including "acknowledgement in the published journal that the publication thereof was a product of the Journal Accreditation Service project of the Commission on Higher Education" in the inside front cover of every issue. Moreover, we have gone beyond the dissemination requirement by providing a complimentary copy of each issue to every Medical School Library in the Philippines.

I ended by reiterating that our journal "has more than complied with the requirements of the Journal Accreditation Service of the Commission on Higher Education for reaccreditation as a Category A Accredited Research Journal, and beg(ged) the honorable review panel to reconsider its recommendation." ${ }^{10}$

It turned out that previously-submitted copies of our journal had been inadvertently misplaced, leading to our downgrade from Category A to B. Expecting full reinstatement, I was surprised to receive a response dated 23 July 2013 on 23 August 2013, informing us that:

"the Technical Evaluators decided to classify the said journal as 'conditional category $A$ ' pending submission of enhanced volumes with sober and serious formats to project scientific/ scholarly image. While refereed journals often contain many graphs and charts, these do not normally include glossy pages (e.g. advertisements) or exciting pictures (e.g. captoons) which noticeably appeared in the issues that you submitted."11

I again respectfully responded to these remarks by citing ${ }^{12}$

the International Committee of Medical Journal Editors Recommendations for the Conduct, Reporting, Editing, and 
Publication of Scholarly Work in Medical Journals (ICMJE Recommendations) updated August 2013, cited 29 August 2013 available at http://www.icmje.org/urm_main.htm/ ${ }^{8}$

The recommendations have clear guidelines on advertising, and do not forbid exciting pictures and cartoons. Nowhere do they constrain scholarly medical journals to maintain "sober and serious formats to project scientific/scholarly image." The Philippine Journal of Otolaryngology Head and Neck Surgery is listed among the Journals Following ICMJE Recommendations http://www.icmje.org/journals.htm/13

The top-tier journals in medicine (BMJ, JAMA, Lancet and NEJM) as well as Science and Nature all have advertising in glossy pages and exciting pictures and cartoons, even on their covers. The same is true for our major journals in the field of Otolaryngology Head and Neck Surgery. I provided the technical panel with copies of the Instructions to Authors of these journals, as well as photographs of actual caricatures from their covers and inside pages. Finally, I also attached an excerpt from: Bennett $\mathrm{HJ}$. Humor in Medicine. South Med J. 2003;96(12) ${ }^{14}$ for the perusal of the honourable Technical Panel.

As of press time, we have not received a reply from the Technical Panel, but have received advise from the Office of Policy, Planning, Research and Information of the Commission on Higher Education to withhold, in the meantime, our inside front cover acknowledgement that the publication of this issue "was a product of the Journal Accreditation Service project of the Commission on Higher Education." However, we shall continue to provide a complimentary copy of this issue to every Medical School Library in the Philippines as a valuable service of our Society and Journal as we await the resolution of this situation.

\section{REFERENCES}

1. Retraction of: Effects of valsartan on morbidity and mortality in uncontrolled hypertensive patients with high cardiovascular risks: KYOTO HEART Study [Eur Heart J (2009) 30: 2461—69, DOI:10.1093/eurheartj/ehp363]. Eur Heart J 2013; 34: 1023.

2. Retraction-Valsartan in a Japanese population with hypertension and other cardiovascular disease (Jikei Heart Study): a randomised, open-label, blinded endpoint morbidity-mortality study. Lancet 2013 Sep; 382(9895):843.

3. Sawada T, Yamada H, Dahlof B, Matsubara H. Effects of valsartan on morbidity and mortality in uncontrolled hypertensive patients with high cardiovascular risks: Kyoto Heart Study. Eur Heart J 2009; 30: 2461-2469.

4. Wood S. Diovan Data-Manipulation Scandal Touches Novartis in Japan. Heartwire. The Heart Org Medscape Cardiology [homepage on the Internet]. July 19, 2013. [cited 2013 November 9]. Available fromhttp://www.medscape.com/viewarticle/808152?t=1

5. Mochizuki S, Dahlof B, Shimizu M, et al. Valsartan in a Japanese population with hypertension and other cardiovascular disease (Jikei Heart Study): a randomised, open-label, blinded endpoint morbidity-mortality study. Lancet 2007; 369: 1431-1439.

6. Husten L. Novartis Acknowledges Employees Participated in 'Independent Trials' Forbes. [homepage on the Internet]. [cited 2013 November 9]. Available from http://www.forbes com/sites/larryhusten/2013/05/23/novartis-acknowledges-its-employees-participated-inindependent-trials/

7. Asia Pacific Association of Medical Journal Editors. "Tokyo Declaration on Research Integrity and Ethical Publication in Science and Medicine in the Asia Pacific Region." Special Announcement in Philipp J Otolaryngol Head Neck Surg 2013 Jul-Dec; 28(2):

8. International Committee of Medical Journal Editors Recommendations for the Conduct Reporting, Editing, and Publication of Scholarly Work in Medical Journals (ICMJE Recommendations) [homepage on the Internet].Updated August 2013. [cited 2013 August 29]. Available from $h$ ttp://www.icmje.org/urm_main.html

9. Tayag JC. [Director, Office of Policy, Planning, research and Information, Commission on Higher Education, Office of the President, Republic of the Philippines]. Letter dated April 26, 2013 to inform (us) that the Philippine Journal of Otolaryngology Head and Neck Surgery has been reaccredited under Category B.

10.Lapena JF. [Editor-in-Chief, Philippine Journal of Otolaryngology Head and Neck Surgery, Philippine Society of Otolaryngology Head and Neck Surgery Inc.] Letter dated May 29, 2013 requesting reconsideration of the accreditation status of the Philippine Journal of Otolaryngology Head and Neck Surgery from Category B to Category A.

11. Tayag JC. [Director, Office of Policy, Planning, research and Information, Commission on Higher Education, Office of the President, Republic of the Philippines]. Letter dated July 23, 2013 in reference to request for reconsideration of the accreditation status of the Philippine Journal of Otolaryngology Head and Neck Surgery from Category B to Category A.

12.Lapena JF. [Editor-in-Chief, Philippine Journal of Otolaryngology Head and Neck Surgery, Philippine Society of Otolaryngology Head and Neck Surgery Inc.] Letter dated August 30, 2013 regarding Conditional Category A status of the Philippine Journal of Otolaryngology Head and Neck Surgery.

13.International Committee of Medical Journal Editors: Journals Following ICMJE Recommendations. [homepage on the Internet]. [cited 2013 August 29]; Available from http:// www.icmje.org/journals.html

14.Bennett HJ. Humor in Medicine. South Med J. 2003 Dec;96(12):1257-61. 